\title{
Identification and quantification of genipin and geniposide from Genipa americana L. by HPLC-DAD using a fused-core column
}

\author{
Grazielle NÁTHIA-NEVES ${ }^{1}$, Gislaine Chystina NOGUEIRA ${ }^{1}$, Renata VARDANEGA ${ }^{1}$, \\ Maria Angela de Almeida MEIRELES ${ }^{1 *}$
}

\begin{abstract}
In this work, it was developed a fast, simple and selective method for quantification of genipin and geniposide from unripe fruits of genipap, which are known as natural colorants, blue and yellow, respectively. The compounds separation was performed in a fused-core $\mathrm{C} 18$ column using as mobile phase water (A) and acetonitrile (B) both acidified with $0.1 \%$ formic acid, with the following gradient: $0 \mathrm{~min}, 99 \% \mathrm{~A} ; 9 \mathrm{~min}, 75 \% \mathrm{~A} ; 10 \mathrm{~min}, 99 \% \mathrm{~A}$ and $13 \mathrm{~min}, 99 \% \mathrm{~A}$. The temperature and flow rate that allowed the best chromatographic performance were $35^{\circ} \mathrm{C}$ and $1.5 \mathrm{~mL} / \mathrm{min}$, respectively, resulting a total run time of $13 \mathrm{~min}$, including column clean-up and re-equilibration. This short analysis time represents an advantage compared to the methods reported in the literature where the running times are 2-5 times greater. The detection wavelength was set at $240 \mathrm{~nm}$. The method validation was performed based on specificity, linearity, detection and quantification limits, precision and accuracy, according to ICH methodology. Finally, the developed method was suitable for monitoring analysis of those compounds content in vegetable samples.
\end{abstract}

Keywords: blue natural colorant; method validation; iridoids.

Practical Application: This method has a great potential to be used by the industry for analysis of genipin and geniposide.

\section{Introduction}

Genipap (Genipa americana L.) belongs to Rubiacea family and Genipa genus. It is a native plant from America, found mainly in Central and South regions of this continent (Djerassi et al., 1960; Ramos-de-la-Peña et al., 2015b). When in its ripe stage the genipap pulp is succulent, acidic and hard which is consumed mainly as juices, jams and liqueurs (Pino et al., 2005; Prance, 2003).

The unripe genipap fruit is rich in iridoids, which are secondary metabolites usually found in many plants, normally as glycosides. Structurally, iridoids are bicyclic monoterpenes (C10), whose basic skeleton is a cyclopentane-[C]-pyran ring typically fused with a six-membered heterocycle oxygenate (Bianco, 1994; Dinda et al., 2007). Among the iridoids present in the fruit, genipin and geniposide stand out as natural sources for obtaining the blue color (Velásquez et al., 2014).

The genipin is a colorless substance, present in unripe fruits of genipap, that is able to react spontaneously in the presence of oxygen, with primary amine groups of amino acids, peptides or proteins and form blue color (Djerassi et al., 1960). The genipin is present in Genipa americana L. in the proportion of $1-3 \%$ of fruit (Ramos-de-la-Peña et al., 2014). The genipin can be obtained directly from genipap by extraction with organic solvents or after enzymatic hydrolysis of geniposide with $\beta$-glycosidases (Ramos-de-la-Peña et al., 2015a; Thomas \& Farrugia, 2013).
The geniposide is often used in Asian countries as a natural colorant and very traditional in Chinese culture for its medicinal effects in treating liver and inflammatory diseases. This iridoid represents about 4 to $6 \%$ of the dry fruit (Butler et al., 2003). The chemical structure of these compounds is shown in Figure 1.

Genipap has been used since ancient times by indigenous for body painting and nowadays it appears as an alternative for obtaining blue colorants for food and chemical industries (Ferreira, 2015). Currently, natural colorants applications have been greatly increased due to the interest for replacing synthetic additives by natural compounds. In addition to providing color, these compounds have biological activity against oxidative damage, inhibition of tumor and anti-inflammatory activities of great interest for pharmaceutical industry (Buchweitz, 2016; Koo et al., 2006).

Genipin and geniposide identification and quantification in real samples are mainly made by High-Performance Liquid Chromatography (HPLC). The major disadvantage of the existing methods is related to the analysis time. Some methods take between 35 and 75 minutes (Bentes \& Mercadante, 2014; Bergonzi et al., 2012; Lee et al., 2014; Li et al., 2016; Wang et al., 2016) which limits its use on genipin and geniposide production scale.

${ }^{1}$ Laboratório de Tecnologia Supercrítica Extração, Fracionamento e Identificação de Extratos Vegetais - LASEFI, Departamento de Engenharia de Alimentos - DEA, Faculdade de Engenharia de Alimentos - FEA, Universidade Estadual de Campinas - UNICAMP, Campinas, SP, Brazil

*Corresponding author: maameireles@gmail.com 


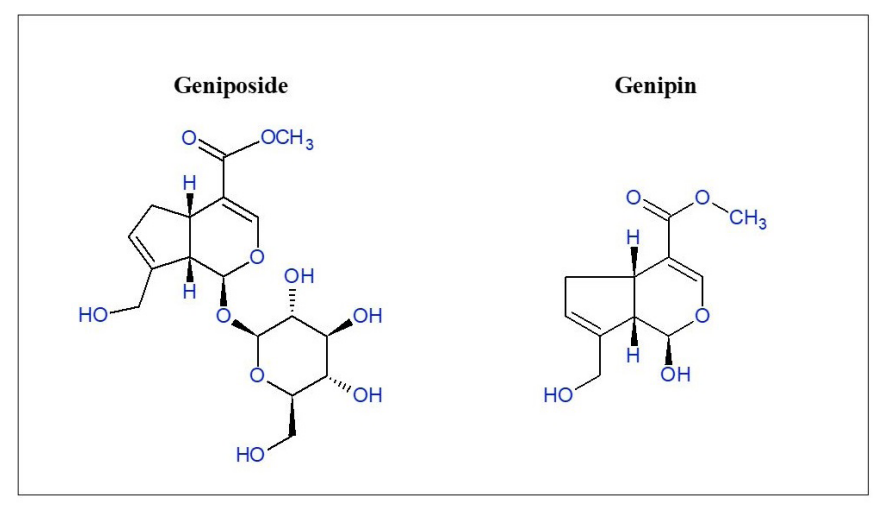

Figure 1. Chemical structure of geniposide and genipin.

To meet the demands for replacing synthetic by natural colorants, new methods to extract selectively these color additives have been developed. Therefore, it is interesting to develop also selective methods for the quantitation of these compounds. The aim of this study was to develop and to validate a reliable and fast HPLC method for simultaneous determination of genipin and geniposide from Genipa americana L. This method is helpful for natural colorants and pharmaceutical industries that use these iridoids in their formulations.

\section{Materials and methods}

\subsection{Chemical and solvents}

HPLC grade acetonitrile was purchased from Scharlau (Barcelona, Spain), formic acid and ethanol was obtained from Dinâmica (São Paulo, Brazil). Ultrapure water was supplied by a Milli-Q Advantage 8 Purifier System from Millipore (Bedford, USA). Genipin and geniposide standards (purity > 98\%) were purchased from Sigma-Aldrich (St. Louis, USA).

\subsection{Samples}

The unripe genipap fruits were obtained from Sítio do Bello (Paraibuna, Brazil). The fruits were frozen with liquid nitrogen and stored in domestic freezer $\left(-20^{\circ} \mathrm{C}\right)$ until being processed for the extraction. The samples were prepared and extracted according to Náthia-Neves et al. (2017). The samples were extracted at $50{ }^{\circ} \mathrm{C}$ and $0.2 \mathrm{MPa}$ with ethanol during $30 \mathrm{~min}$. For each extraction assay $4 \mathrm{~g}$ of raw material and $20 \mathrm{~g}$ of solvent were used, resulting in a solvent to sample ratio of 5:1. After the extraction, the extracts were filtered through a $0.45 \mu \mathrm{m}$ nylon seringe filter (Sinergia Cientifica, Campinas, Brazil) and diluted 5 times $(200 \mu \mathrm{L}$ of extract in $800 \mu \mathrm{L}$ of solvent $)$ to acetonitrile:water (1:1) for chromatographic analysis.

\subsection{Chromatographic instrumentation}

HPLC analysis was carried out on an Alliance 2695/2695D Separation Module (Waters, Milford, USA) with integrated column heater and auto-sampler and a photodiode array detector (2998, Waters, Milford, USA). Compounds separation was carried out on a fused-core $\mathrm{C}_{18}$ column (Kinetex, $100 \times 4.6 \mathrm{~mm}$ i.d.; $2.6 \mu \mathrm{m}$; Phenomenex, Torrance, USA). The kinetic dead volume $\left(\mathrm{V}_{\mathrm{m}}\right)$ of the column was $740 \pm 5 \mu \mathrm{L}$ and the extra-column volume was $62.5 \pm 0.1 \mu \mathrm{L}$, as described in a previous study (Osorio-Tobón et al., 2016). The HPLC system dwell volume was described by the manufacturer as $<650 \mu \mathrm{L}$.

\section{Chromatographic conditions development}

The mesocarp ethanolic extract from genipap was the sample employed in all the chromatographic tests for the quantification of iridoids genipin and geniposide. The chromatographic conditions tested were the mobile phase composition consisted of water (acidified or not with formic acid $0.1 \% \mathrm{v} / \mathrm{v}$, solvent $\mathrm{A}$ ) and acetonitrile (acidified or not with formic acid $0.1 \%$, $\mathrm{v} / \mathrm{v}$, solvent $\mathrm{B})$, temperatures $\left(30,35\right.$ and $\left.40{ }^{\circ} \mathrm{C}\right)$, flow rates (0.5, 1.0 and $1.5 \mathrm{~mL} / \mathrm{min})$ and equilibration times (1-5 $\mathrm{min})$. UV spectra was monitored between 200 and $600 \mathrm{~nm}$ and the peaks of the iridoids were integrated at $240 \mathrm{~nm}$.

\section{Method validation}

The method was validated according to $\mathrm{ICH}$ guidelines based on specificity, linearity and range, limits of detection and quantification, precision and accuracy (International Council for Harmonisation, 2005), with some adaptations to food material.

\section{Specificity}

The identification of iridoids present in the sample was achieved by the comparison of retention times and UV spectra of separated compounds with the authentic standard. Column efficiency was evaluated on basis of retention time, width, K prime, selectivity, symmetry factor, width at baseline and resolution of the peaks of iridoids geniposide and genipin. All performance parameters were calculated using the US Pharmacopeia (USP) option by the Empower 3 software.

\section{Linearity and range}

The stock solution of genipin standard was prepared by dissolving $25 \mathrm{mg}$ of genipin in $10 \mathrm{~mL}$ of acetonitrile:water $(1: 1)$. The stock solution of geniposide standard was prepared by dissolving $10 \mathrm{mg}$ of geniposide in $10 \mathrm{~mL}$ of acetonitrile:water (1:1). The curve of each iridoids was prepared in triplicate by plotting the concentration $(0.1-1000 \mu \mathrm{g} / \mathrm{mL}$ for geniposide and $0.1-2500 \mu \mathrm{g} / \mathrm{mL}$ for genipin) against area of the peak. Regression equations and correlation coefficient $\left(\mathrm{r}^{2}\right)$ were calculated using OriginPro $^{\circledR}$ v. 9.0 software.

\section{Limits of detection and quantitation}

The limit of detection (LoD) and limit of quantitation (LoQ) were determined by calculation of the signal-to-noise ratio. A signal-to-noise ratio of 3:1 was considered for estimating the LoD and the signal-to-noise ratio of 10:1 corresponded to the LoQ.

Precision and accuracy

The repeatability and intermediate precision of the developed method were evaluated in terms of peak area and retention time of the iridoids. A total of 30 HPLC analyses were performed 
on three successive days (10 analyses per day) using the same sample, a mesocarp ethanolic extract from genipap.

The accuracy of the method was tested by the spiking/recovery technique. Firstly, three independent solutions of extract were prepared with the following iridoid concentrations: $28.65,64.21$ and $124.40 \mu \mathrm{g} / \mathrm{mL}$. $200 \mu \mathrm{L}$ of each solution were spiked with $3.86 \mu \mathrm{g}$ of geniposide and $3.13 \mu \mathrm{g}$ of genipin by adding $70 \mu \mathrm{L}$ of each standard solution containing $55.15 \mu \mathrm{g} / \mathrm{mL}$ and $44.70 \mu \mathrm{g} / \mathrm{mL}$ of geniposide and genipin, respectively and each one was injected three times. The average percentage recovery was calculated for each level of concentration.

\section{Results and discussion}

\subsection{Optimization of chromatographic conditions}

The better overall peaks separation and resolution were obtained with the solvents acidified with formic acid. The reduction of $\mathrm{pH}$ of the mobile phase is commonly used for the separation of iridoids (Bentes \& Mercadante, 2014; Bergonzi et al., 2012) as well as other bioactive compounds, such as curcurminoids (Osorio-Tobón et al., 2016), beta-ecdysone (Rostagno et al., 2014) and bixin (Chisté et al., 2011), among others.

The column temperature selected was $35{ }^{\circ} \mathrm{C}$ because a better resolution and reproducibility were obtained and it was below the maximum column operating temperature of $60^{\circ} \mathrm{C}$. The increase of temperature slightly decreased the retention time of iridoids. In the literature, temperatures between 25 and $30{ }^{\circ} \mathrm{C}$ were used for iridoids separation (Bentes \& Mercadante, 2014; Bergonzi et al., 2012; Wang et al., 2016).

The mobile phase flow rate was increased step-by-step from 0.5 to $1.5 \mathrm{~mL} / \mathrm{min}$. Maintaining the temperature column at $35^{\circ} \mathrm{C}$, the retention time decreased $40 \%$ for the iridoids by increasing the flow rate. The separation of the iridoids was achieved in approximately 9 minutes, which is a short time for the separation of the compounds. Re-equilibration time is necessary in gradient HPLC to ensure that the column environment has returned to the initial stable conditions. These conditions are particularly important when using gradient elution because the difference between the initial and final organic composition of the mobile phase is significant (Zabot et al., 2014). It was necessary $4 \mathrm{~min}$ between runs to clean-up and return to the initial conditions of the method. The re-equilibration time represent $31 \%$ of the total run time, which was 13 minutes (including elution, clean-up and re-equilibration) and is equivalent to 9.4 volumes of the column.

\subsection{Characteristics of the HPLC method}

The optimized conditions of the chromatographic method consisted of the following gradient: $0 \mathrm{~min}, 99 \% \mathrm{~A} ; 9 \mathrm{~min}$, 75\% A; $10 \mathrm{~min}, 99 \% \mathrm{~A}$ and $13 \mathrm{~min}, 99 \% \mathrm{~A}$. The column was maintained at $35^{\circ} \mathrm{C}$, working with a flow rate of $1.5 \mathrm{~mL} / \mathrm{min}$ and a re-equilibration time of 4 minutes. Representative chromatograms of the ethanolic extract of genipap and the iridoids standards are shown in Figure 2. Genipin and geniposide were identified through the retention times and maximum absorption wavelength.

The retention times of geniposide and genipin were 5.73 and 6.65 , respectively. The elution order was the same observed by other authors (Bentes \& Mercadante, 2014; Wang et al., 2016). However, duration of the methods reported in the literature is much longer (up to $75 \mathrm{~min}$ ) when compared to the obtained in this study (13 min). Resolution, width of peaks, selectivity, symmetry factor and $\mathrm{K}$ prime were calculated by Empower 3 software and were for geniposide 1.62, 15.37, 1.05, 0.90 and 1.30; for genipin were $1.74,15.37,1.05 ; 0.91$ and 1.67 , respectively. These results indicate the good chromatographic method developed for the separation of iridoids because the resolution for the both compounds was higher than 1.5 and the symmetry factor was 0.90 . The parameters mentioned above were not found in the methods reported in the literature.
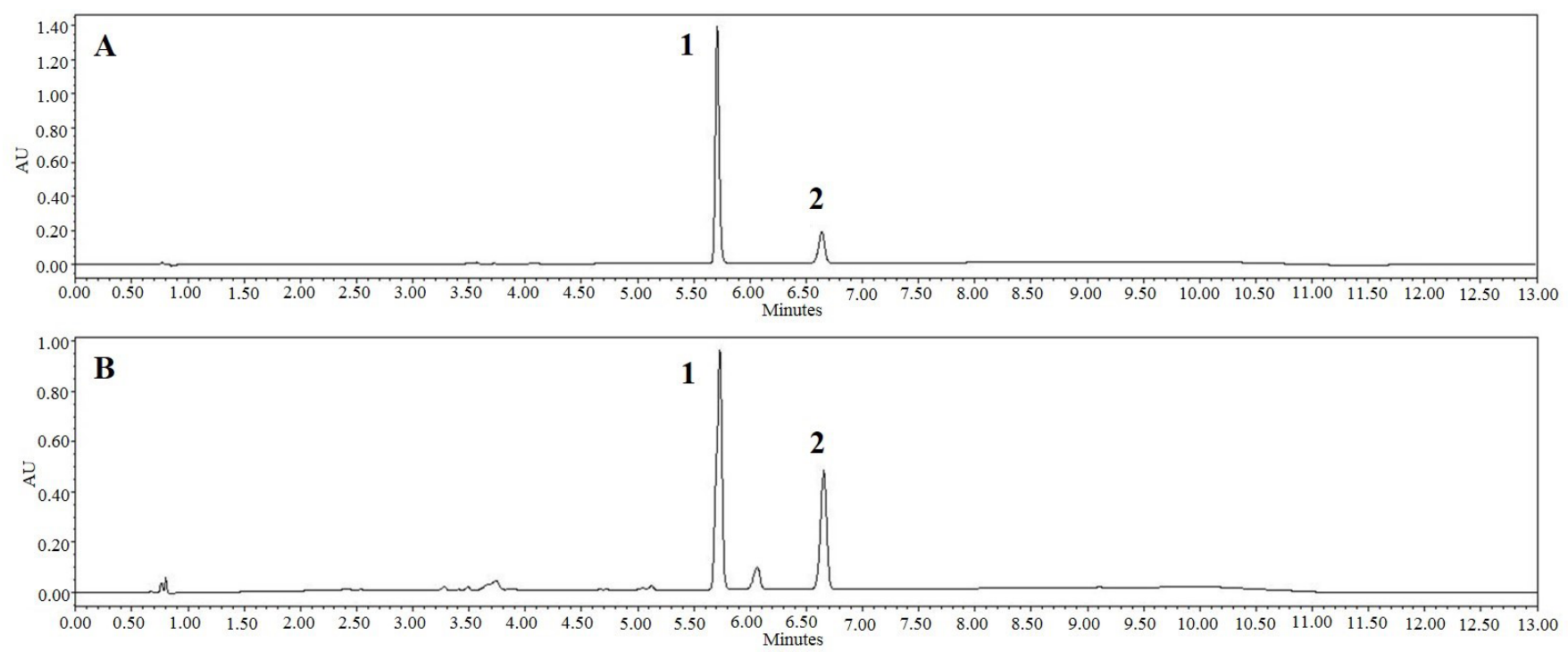

Figure 2. Representative chromatograms of the iridoids standards (A) and ethanolic extract of genipap (B). Geniposide (peak 1) and genipin (peak 2). 


\subsection{Method validation}

\section{Linearity and range}

Linearity was determined for geniposide and genipin on eleven and ten levels of concentration, respectively. Geniposide showed a linear response from $0.41-1000 \mu \mathrm{g} / \mathrm{mL}$ and genipin showed a linear response from 0.41-625 $\mu \mathrm{g} / \mathrm{mL}$. All curves presented coefficients of linear correlation higher than 0.9998 . Geniposide linearity found in the methods reported in the literature was between 1.0 and $1000 \mu \mathrm{g} / \mathrm{mL}$ (Bergonzi et al., 2012; Liu et al., 2011; Sheu \& Hsin, 1998; Wu et al., 2014) and genipin linearity was between 0.5 and $100 \mu \mathrm{g} / \mathrm{mL}$ (Bentes \& Mercadante, 2014; Wu et al., 2014).

\section{Limit of detection and quantification}

Geniposide and genipin at a concentration of $0.41 \mu \mathrm{g} / \mathrm{mL}$ presented a signal-to-noise ratio higher than $3: 1$, which were assumed as the limit of detection (LoD) for the both compounds. Geniposide at $6.5 \mu \mathrm{g} / \mathrm{mL}$ and genipin at $1.63 \mu \mathrm{g} / \mathrm{mL}$ presented a signal-to-noise ratio higher than 10:1, representing the limit of quantification (LoQ). The genipin limits were similar to reported by Bentes \& Mercadante (2014), while the geniposide limits were approximately 10 times higher than the reported in the literature (Bergonzi et al., 2012; Liu et al., 2011; Wu et al., 2014).

\section{Robustness}

Table 1 shows the robustness results for the developed method concerning sample concentration/dilution and injection volume, respectively. The chromatographic performance was slightly affected by the sample concentration and injected volume. These results are related to the high performance of the fused-column used in this study because columns with this technology can operate with low amount of sample due to an increased diffusion of the sample in the solvent (Osorio-Tobón et al., 2016).

\section{Precision and accuracy}

The intraday and interday precision were evaluated in terms of retention time and peak area by injecting the sample 10 times within a day and by duplicating the experiment once a day during three consecutive days. The relative standard deviation (RSD) was lower than $0.04 \%$ for retention time and lower than $0.67 \%$ for peak area for the intraday precision. For interday precision the RSD was lower than $0.03 \%$ and $3.05 \%$ for retention time and peak area, respectively.

The accuracy of the developed method was determined by analyzing the percentage recovery of the both iridoids into different concentration levels of the genipap extract. As shown in Table 2, the geniposide recovery ranged between 95.0 and $96.8 \%$, while the genipin recovery ranged between 103.5 and $110.5 \%$.

\section{Specificity}

No deviations were observed in the geniposide and genipin UV-spectra at the beginning, at the apex and at the end of peaks of each constituent obtained from the genipap extract sample (Figure 3), demonstrating the purity of the peaks.

\subsection{Application to real samples}

To evaluate the performance of the chromatographic method, these iridoids were quantified in ethanolic extracts obtained from different parts of the genipap fruit. Figure 4 shows the chromatograms of the ethanolic extracts obtained for five different

Table 1. Effect of sample concentration and injection volume on the chromatographic performance.

\begin{tabular}{|c|c|c|c|c|c|c|c|c|}
\hline & Compound & $\mathrm{RT}(\min )$ & $\begin{array}{c}\text { Concentration } \\
(\mu \mathrm{g} / \mathrm{mL})\end{array}$ & Width (s) & K prime & Selectivity & Resolution & $\begin{array}{c}\text { Symmetry } \\
\text { factor }\end{array}$ \\
\hline \multicolumn{9}{|c|}{ Dilution } \\
\hline \multirow[t]{2}{*}[\mathrm{X}_{0}]{$/ 1$} & Geniposide & 5.730 & 351.56 & 15.57 & 1.30 & 1.06 & 1.56 & 0.96 \\
\hline & Genipin & 6.649 & 125.01 & 15.20 & 1.67 & 1.05 & - & 0.92 \\
\hline \multirow[t]{2}{*}[\mathrm{X}_{0}]{$/ 2$} & Geniposide & 5.734 & 337.53 & 15.37 & 1.30 & 1.05 & 1.62 & 0.90 \\
\hline & Genipin & 6.653 & 121.15 & 15.37 & 1.67 & 1.05 & 1.74 & 0.91 \\
\hline \multirow[t]{2}{*}[\mathrm{X}_{0}]{$/ 3$} & Geniposide & 5.733 & 344.72 & 15.10 & 1.30 & 1.04 & 2.12 & 0.87 \\
\hline & Genipin & 6.651 & 125.40 & 14.77 & 1.67 & 1.05 & - & 0.91 \\
\hline \multirow[t]{2}{*}[\mathrm{X}_{0}]{$/ 4$} & Geniposide & 5.658 & 306.67 & 15.03 & 1.30 & 1.05 & 1.70 & 0.87 \\
\hline & Genipin & 6.597 & 111.80 & 15.70 & 1.67 & 1.07 & 2.65 & 0.90 \\
\hline \multirow[t]{2}{*}[\mathrm{X}_{0}]{$/ 5$} & Geniposide & 5.729 & 360.40 & 14.97 & 1.30 & 1.06 & 1.69 & 0.85 \\
\hline & Genipin & 6.648 & 132.52 & 15.70 & 1.67 & 1.07 & 3.92 & 0.91 \\
\hline \multicolumn{9}{|c|}{ Injection volume } \\
\hline \multirow[t]{2}{*}{2.5} & Geniposide & 5.741 & 278.27 & 16.2 & 1.30 & 1.06 & 1.72 & 1.11 \\
\hline & Genipin & 6.661 & 102.76 & 14.7 & 1.67 & 1.07 & 3.6 & 0.90 \\
\hline \multirow[t]{2}{*}{5} & Geniposide & 5.732 & 327.10 & 16.2 & 1.30 & 1.08 & 2.16 & 1.12 \\
\hline & Genipin & 6.660 & 117.51 & 15.0 & 1.67 & 1.06 & 3.74 & 0.91 \\
\hline \multirow[t]{2}{*}{10} & Geniposide & 5.724 & 360.40 & 14.97 & 1.30 & 1.06 & 1.69 & 0.85 \\
\hline & Genipin & 6.650 & 132.52 & 15.70 & 1.67 & 1.07 & 3.92 & 0.91 \\
\hline \multirow[t]{2}{*}{15} & Geniposide & 5.73 & 359.59 & 21.5 & 1.30 & 1.06 & 1.68 & 0.68 \\
\hline & Genipin & 6.64 & 127.47 & 16.5 & 1.67 & 1.047 & 2.14 & 0.90 \\
\hline \multirow[t]{2}{*}{20} & Geniposide & 5.718 & 358.57 & 23.7 & 1.30 & 1.10 & 3.6 & 0.59 \\
\hline & Genipin & 6.637 & 126.96 & 25.90 & 1.66 & 1.10 & 2.503 & 0.81 \\
\hline
\end{tabular}



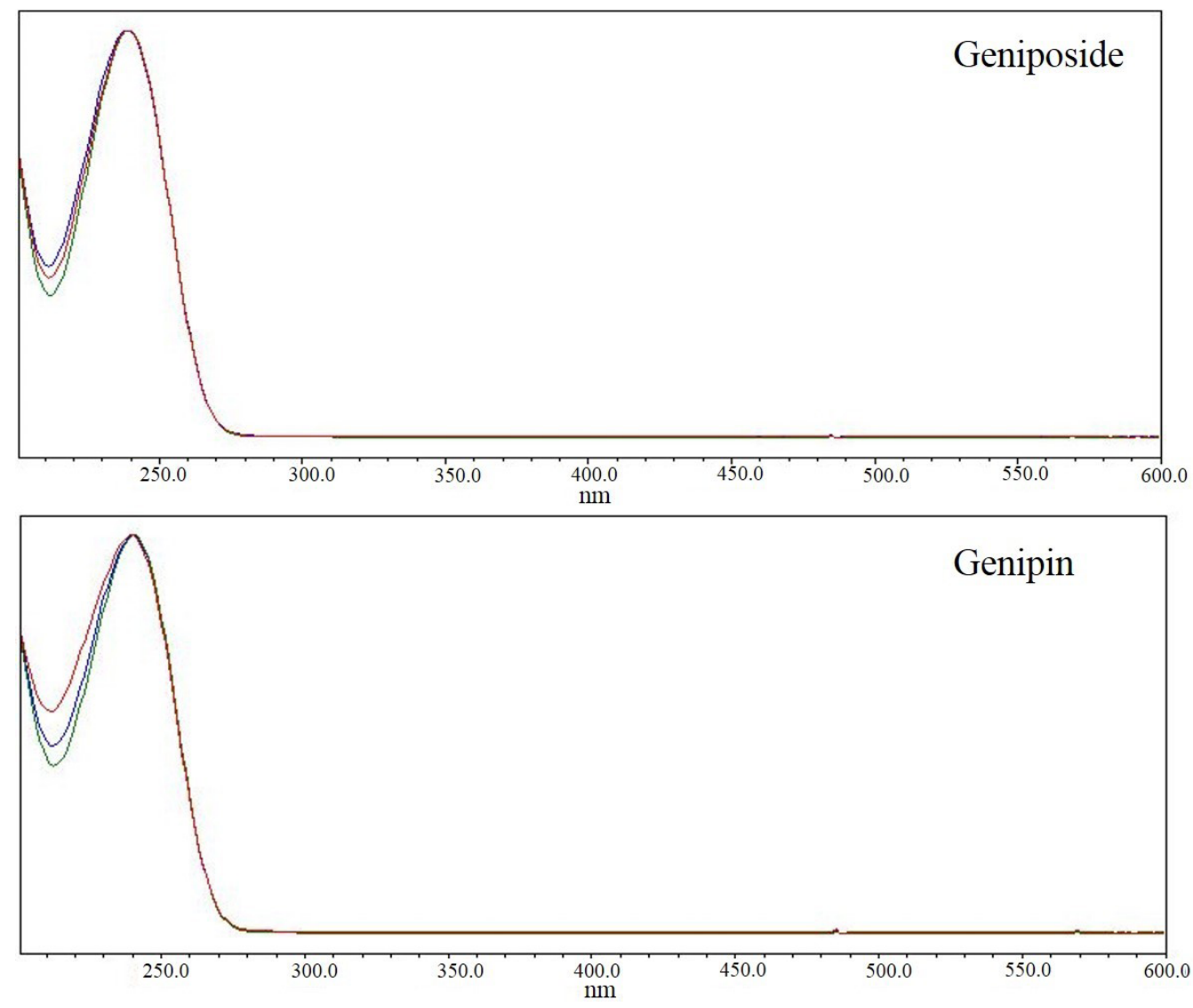

Figure 3. Overlay of three UV-spectra $(240 \mathrm{~nm})$ at the beginning, at the apex and at the end of the peaks of geniposide at $5.73 \mathrm{~min}$ and genipin at $6.65 \mathrm{~min}$.
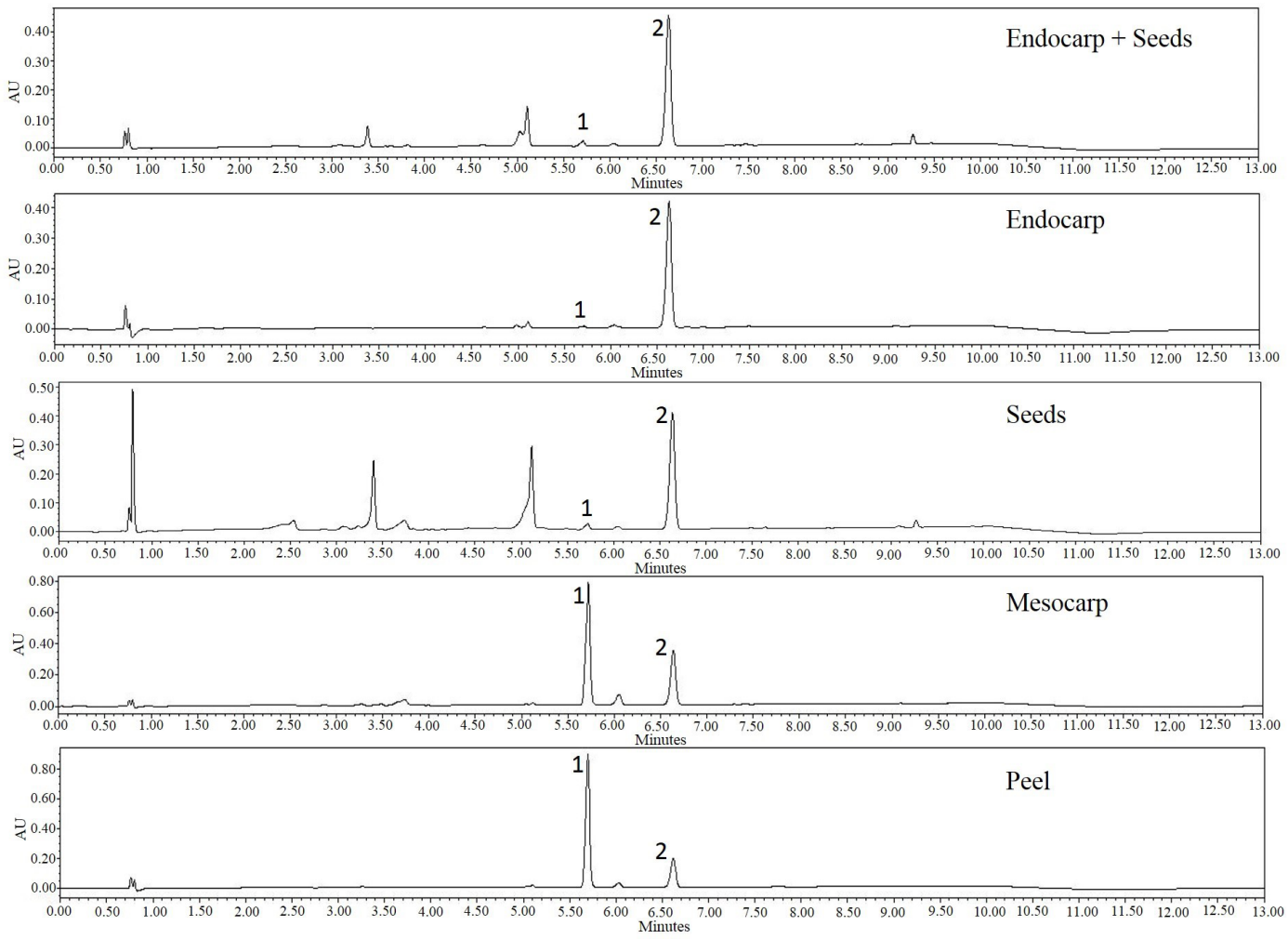

Figure 4. Representative chromatograms of the ethanolic extract from different parts of genipap fruit. Geniposide (peak 1) and genipin (peak 2). 
Table 2. Recovery of iridoids.

\begin{tabular}{cccccc}
\hline Analyte & $\begin{array}{c}\text { Original } \\
\text { amount }(\mu \mathrm{g})\end{array}$ & $\begin{array}{c}\text { Spiked } \\
(\mu \mathrm{g})\end{array}$ & $\begin{array}{c}\text { Found } \\
(\mu \mathrm{g})\end{array}$ & $\begin{array}{c}\text { Recovery } \\
(\%)\end{array}$ & RSD (\%) \\
\hline Geniposide & 24.70 & 3.86 & 27.54 & 96.8 & 2.3 \\
& 12.84 & 3.86 & 16.12 & 96.4 & 0.3 \\
\multirow{6}{*}{ Genipin } & 5.73 & 3.86 & 9.11 & 95.0 & 0.8 \\
& 8.64 & 3.13 & 12.15 & 103.5 & 2.1 \\
& 4.49 & 3.13 & 8.18 & 107.2 & 0.8 \\
& 2.01 & 3.13 & 5.71 & 110.5 & 1.1 \\
\hline
\end{tabular}

RSD: Relative standard deviation.

Table 3. Concentration of iridoids ( $\mathrm{mg} / \mathrm{g}$ of raw material) in different unripe genipap fruit parts.

\begin{tabular}{lccc}
\hline & Geniposide & Genipin & Total Iridoids \\
\hline Endocarp + seeds & 0.12 & 23.07 & 23.19 \\
Endocarp & 0.08 & 38.96 & 39.04 \\
Seeds & 0.06 & 1.17 & 1.23 \\
Mesocarp & 58.70 & 20.65 & 79.35 \\
Peel & 40.25 & 7.51 & 47.76 \\
\hline
\end{tabular}

RSD: Relative standard deviation.

parts (endocarp + seeds, endocarp, seeds, mesocarp and peel) of the genipap fruit. The concentration of iridoids recovered from each part of the fruit is shown in Table 3. The iridoids profiles observed in Figure 4 were not directly proportional because the samples needed to be differently diluted in order to achieve the linear range for both compounds. Geniposide was mainly found in mesocarp (58.7 mg/g) and peel $(40.25 \mathrm{mg} / \mathrm{g})$ of the fruit, whereas significant amount of genipin was observed in all parts of the fruit except for seeds, which showed a content of $1.17 \mathrm{mg} / \mathrm{g}$. Regarding the total iridoids recovery, the seeds also presented the lowest value $(1.23 \mathrm{mg} / \mathrm{g})$, while the mesocarp showed the highest $(79.35 \mathrm{mg} / \mathrm{g})$. This result corroborates the literature that reports the mesocarp as the main source of geniposide and the endocarp as the main source of genipin (Bentes \& Mercadante, 2014). The results indicated that the proposed method was successfully applied to quantitatively analyze the main iridoids of the genipap fruit.

\section{Conclusions}

The two major iridoids from genipap fruit were accurately separated and quantified in a short time of $13 \mathrm{~min}$ of analysis. The method showed an excellent performance regarding the simplicity, precision, accuracy and robustness. The validated data showed a good performance for the different dilutions and injection volumes tested and also presented low deviation in terms of intermediate precision. This method has a great potential to be used by the industry for analysis of genipin and geniposide.

\section{Acknowledgements}

The authors are grateful to Sao Paulo Research Foundation (FAPESP 2015/13299-0) for financial support. G. Náthia-Neves thanks Coordination for the Improvement for the Higher Education Personnel (CAPES) for a Ph.D. assistantship. G.C. Nogueira and R. Vardanega thank National Council for Scientific and Technological Development (CNPq) for the P.D. assistantship
(166060/2015-1 and 152148/2016-7). M.A.A. Meireles thanks CNPq for the productivity grant (302423/2015-0).

\section{References}

Bentes, A. S., \& Mercadante, A. Z. (2014). Influence of the stage of ripeness on the composition of iridoids and phenolic compounds in genipap (Genipa americana L.). Journal of Agricultural and Food Chemistry, 62(44), 10800-10808. PMid:25323434. http://dx.doi. org/10.1021/jf503378k.

Bergonzi, M. C., Righeschi, C., Isacchi, B., \& Bilia, A. R. (2012). Identification and quantification of constituents of Gardenia jasminoides Ellis (Zhizi) by HPLC-DAD-ESI-MS. Food Chemistry, 134(2), 1199-1204. PMid:23107748. http://dx.doi.org/10.1016/j. foodchem.2012.02.157.

Bianco, A. (1994). Recent developments in iridoids chemistry. Pure and Applied Chemistry, 66(10-11), 2335-2338. http://dx.doi.org/10.1351/ pac199466102335.

Buchweitz, M. (2016). Natural solutions for blue colors in food. In R. Carle \& R. Schweiggert (Eds.), Handbook on natural pigments in food and beverages: industrial applications for improving food color (355 p.). Cambridge: Elsevier.

Butler, M. F., Ng, Y.-F., \& Pudney, P. D. A. (2003). Mechanism and kinetics of the crosslinking reaction between biopolymers containing primary amine groups and genipin. Journal of Polymer Science. Part A, Polymer Chemistry, 41(24), 3941-3953. http://dx.doi.org/10.1002/ pola.10960.

Chisté, R. C., Yamashita, F., Gozzo, F. C., \& Mercadante, A. Z. (2011). Simultaneous extraction and analysis by high performance liquid chromatography coupled to diode array and mass spectrometric detectors of bixin and phenolic compounds from annatto seeds. Journal of Chromatography A, 1218(1), 57-63. PMid:21111424. http://dx.doi.org/10.1016/j.chroma.2010.10.094.

Dinda, B., Debnath, S., \& Harigaya, Y. (2007). Naturally occurring iridoids: a review, Part 1. Chemical \& Pharmaceutical Bulletin, 55(2), 159-222. PMid:17268091. http://dx.doi.org/10.1248/cpb.55.159.

Djerassi, C., Gray, J. D., \& Kincl, F. A. (1960). Naturally occurring oxygen heterocyclics. IX. ${ }^{1}$ Isolation and characterization of genipin ${ }^{2}$. The Journal of Organic Chemistry, 25(12), 2174-2177. http://dx.doi. org/10.1021/jo01082a022.

Ferreira, M. K. L. (2015). Introduction. In M. K. L. Ferreira, Mapping time, space and the body: indigenous knowledge and mathematical thinking in Brazil (pp. 1-28). Rotterdam: SensePublishers.

International Council for Harmonisation - ICH. (2005). Harmonised tripartite guideline: validation of analytical procedures: text and methodology Q2 (R1). In International Conference on Harmonization of Technical Requirements for the Registration of Pharmaceuticals for Human Use (pp. 13). Geneva: ICH.

Koo, H. J., Lim, K. H., Jung, H. J., \& Park, E. H. (2006). Anti-inflammatory evaluation of gardenia extract, geniposide and genipin. Journal of Ethnopharmacology, 103(3), 496-500. PMid:16169698. http://dx.doi. org/10.1016/j.jep.2005.08.011.

Lee, E. J., Hong, J. K., \& Whang, W. K. (2014). Simultaneous determination of bioactive marker compounds from Gardeniae fructus by high performance liquid chromatography. Archives of Pharmacal Research, 37(8), 992-1000. PMid:24277694. http://dx.doi.org/10.1007/s12272013-0293-1.

Li, J., Xu, B., Zhang, Y., Dai, S., Sun, F., Shi, X., \& Qiao, Y. (2016). Determination of geniposide in Gardenia jasminoides Ellis fruit by near-infrared spectroscopy and chemometrics. Analytical Letters, 49(13), 2063-2076. http://dx.doi.org/10.1080/00032719.2015.1130714. 
Liu, H., Su, J., Liang, X., Zhang, X., He, Y.-J., Huang, H.-Q., Ye, J., \& Zhang, W.-D. (2011). Identification and determination of the major constituents in traditional Chinese medicine Longdan Xiegan Pill by HPLC-DAD-ESI-MS. Journal of Pharmaceutical Analysis, 1(1), 1-7. http://dx.doi.org/10.1016/S2095-1779(11)70001-6.

Náthia-Neves, G., Tarone, A. G., Tosi, M. M., Maróstica Júnior, M. R., \& Meireles, M. A. A. (2017). Extraction of bioactive compounds from genipap (Genipa americana L.) by pressurized ethanol: Iridoids, phenolic content and antioxidant activity. Food Research International, 102, 595-604. PMid:29195990. http://dx.doi.org/10.1016/j. foodres.2017.09.041.

Osorio-Tobón, J. F., Carvalho, P. I. N., Barbero, G. F., Nogueira, G. C., Rostagno, M. A., \& Meireles, M. A. A. (2016). Fast analysis of curcuminoids from turmeric (Curcuma longa L.) by highperformance liquid chromatography using a fused-core column. Food Chemistry, 200, 167-174. PMid:26830575. http://dx.doi. org/10.1016/j.foodchem.2016.01.021.

Pino, J., Marbot, R., \& Vazquez, C. (2005). Volatile constituents of genipap (Genipa americana L.) fruit from Cuba. Flavour and Fragrance Journal, 20(6), 583-586. http://dx.doi.org/10.1002/ffj.1491.

Prance, G. T. (2003). Fruits of tropical climates: fruits of Central and South America. In B. Caballero (Ed.), Encyclopedia of food sciences and nutrition (2nd ed., pp. 2810-2816). Oxford: Academic Press.

Ramos-de-la-Peña, A. M., Renard, C. M., Wicker, L., Montanez, J. C., Garcia-Cerda, L. A., \& Contreras-Esquivel, J. C. (2014). Environmental friendly cold-mechanical/sonic enzymatic assisted extraction of genipin from genipap (Genipa americana). Ultrasonics Sonochemistry, 21(1), 43-49. PMid:23871416. http://dx.doi. org/10.1016/j.ultsonch.2013.06.008.

Ramos-de-la-Peña, A. M., Renard, C. M. G. C., Montañez, J. C., ReyesVega, M. L., \& Contreras-Esquivel, J. C. (2015a). Ultrafiltration for genipin recovery technologies after ultrasonic treatment of genipap fruit. Biocatalysis and Agricultural Biotechnology, 4(1), 11-16. http:// dx.doi.org/10.1016/j.bcab.2014.09.009.

Ramos-de-la-Peña, A. M., Montañez, J. C., Reyes-Vega, M. L., \& Contreras-Esquivel, J. C. (2015b). Temperature model for process impact non-uniformity in genipin recovery by high pressure processing. Food Chemistry, 187, 444-450. PMid:25977049. http:// dx.doi.org/10.1016/j.foodchem.2015.04.114.

Rostagno, M. A., Debien, I. C. N., Vardanega, R., Nogueira, G. C., Barbero, G. F., \& Meireles, M. A. A. (2014). Fast analysis of beta-ecdysone in Brazilian ginseng (Pfaffia glomerata) extracts by high-performance liquid chromatography using a fused-core column. Analytical Methods, 6(8), 2452-2459. http://dx.doi.org/10.1039/C3AY42276C.

Sheu, S. J., \& Hsin, W. C. (1998). Identification and determination of the major constituents in traditional Chinese medicine Longdan Xiegan Pill by HPLC-DAD-ESI-MS. Journal of Separation Science, 21(9), 523-526.

Thomas, P., \& Farrugia, K. (2013). An investigation into the enhancement of fingermarks in blood on paper with genipin and lawsone. Science \& Justice, 53(3), 315-320. PMid:23937940. http://dx.doi.org/10.1016/j. scijus.2013.04.006.

Velásquez, C. L., Rivas, A., \& Ocanto, I. S. (2014). Obtención de Genipina a partir de frutos de caruto (Genipa americana L.) del llano venezolano. Avances en Química, 9(2), 75-86.

Wang, L., Liu, S., Zhang, X., Xing, J., Liu, Z., \& Song, F. (2016). A strategy for identification and structural characterization of compounds from Gardenia jasminoides by integrating macroporous resin column chromatography and liquid chromatography-tandem mass spectrometry combined with ion-mobility spectrometry. Journal of Chromatography. A, 1452, 47-57. PMid:27208986. http://dx.doi. org/10.1016/j.chroma.2016.05.026.

Wu, X., Zhou, Y., Yin, F., Mao, C., Li, L., Cai, B., \& Lu, T. (2014). Quality control and producing areas differentiation of Gardeniae Fructus for eight bioactive constituents by HPLC-DAD-ESI/MS. Phytomedicine, 21(4), 551-559. PMid:24183952. http://dx.doi. org/10.1016/j.phymed.2013.10.002.

Zabot, G. L., Moraes, M. N., Rostagno, M. A., \& Meireles, M. A. A. (2014). Fast analysis of phenolic terpenes by high-performance liquid chromatography using a fused-core column. Analytical Methods, 6(18), 7457-7468. http://dx.doi.org/10.1039/C4AY01124D. 